\title{
Avaliação De Pacientes Com Cirrose, Atendidos Em Nível Ambulatorial, Submetidos A Transplante Hepático
}

\author{
Silva, R.R.; Mattos, A.A.; John, J.A.; Miozzo, S.A.S.; Porto, M.; Comerlato, \\ P.H.; Contiero, P.;
}

Apresentador: Silva $R R$

\section{Resumo}

Introdução: O Transplante Ortotópico de Fígado (TOF) aumenta significativamente a sobrevida e a qualidade de vida dos pacientes cirróticos em estágio terminal. Esse estudo avaliou as características dos pacientes com cirrose, submetidos á TOF, acompanhados em ambulatório terciário, levando-se em consideração a classificação etiológica da doença. Métodos: Foi realizado um estudo de coorte, observacional e retrospectivo, avaliando-se os pacientes portadores de cirrose em acompanhamento ambulatorial entre março de 2005 a março de 2010, por meio de revisão de prontuários. Foram incluídos todos os pacientes com diagnóstico de cirrose e seguimento mínimo de um ano. Foram excluídos casos de co-infecção com HIV, transplante de órgãos prévio, diagnóstico de $\mathrm{CHC}$ avançado no primeiro atendimento, ausência de registros e perda de seguimento. Critérios para etiologias: Vírus $\mathrm{C}(\mathrm{VHC})$ - anti-HCV + PCR, Vírus B (VHB) HBsAg + PCR, álcool - ingestão $>80 \mathrm{~g} / \mathrm{d}$ por 10 anos (homens) ou 40g (mulheres) outros - diagnóstico histológico ou por exclusão $\mathrm{O}$ projeto foi aprovado pelo CEP institucional. Na comparação de variáveis categóricas utilizamos o teste do qui-quadrado. $\mathrm{O}$ nível de significância do estudo foi de $?=0,05$. Os dados foram analisados com o programa SPSS 18.0.
Resultados: Foram submetidos a TOF 60 pacientes (11\% do total de 527$)$, média de idade $(51,9 \pm 10)$, sexo masculino (67\%) e Child B ou C (87\%), com MELD médio $(15,5 \pm 4,3)$ e presença de $\mathrm{CHC}$ em 20 pacientes (33\%). Houve diferença entre o grupo VHC de maior média $(55,5 \pm 5,6)$ e grupo de outras etiologias com menor média de idade $(44,5 \pm 14,8)$ $(\mathrm{p}=0,017)$ predomínio do sexo masculino no grupo $\mathrm{VHC}+$ álcool (94\%) e do sexo feminino no grupo VHC $(63 \%)(p=0,001)$ presença de CHC nos três primeiros grupos $(37 \%, 50 \%, 44 \%)$, e nenhum caso no grupo outros $(\mathrm{p}=0,005)$. Conclusão: Nos pacientes submetidos a TOF, a média de idade foi maior no grupo de etiologia por VHC. Houve maior prevalência do sexo masculino, exceto no grupo VHC, no qual prevaleceu o sexo feminino. Observou-se maior desenvolvimento de $\mathrm{CHC}$ nos grupos VHC, VHC+Álcool e Álcool.

\section{Referência:}

Silva, R.R.; Mattos, A.A.; John, J.A.; Miozzo, S.A.S.; Porto, M.; Comerlato, P.H.; Contiero, P.;. Avaliação De Pacientes Com Cirrose, Atendidos Em Nível Ambulatorial, Submetidos A Transplante Hepático. In: II Congresso Brasileiro de Medicina Hospitalar - II CBMH [= Blucher Medical Proceedings, vol.1, num.5] São Paulo: Editora Blucher, 2014. p.64 DOI 10.5151/medpro-II-cbmh-061 